\title{
CLOTHED STRAW PUPPETS IN ESTONIAN FOLK CALENDAR TRADITION: A SHIFT FROM CULT TO JOKE? *
}

\section{Ergo-Hart Västrik}

In our country at the time of the end of the rule of the Swedish kings there was in some places the pagan custom, known also elsewhere in the world. On Shrove Tuesday people made a puppet figure which

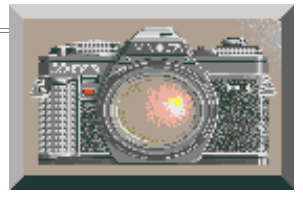
they called metsik [the Wild One]. One year they put on it a man's hat and an old coat, the next year they put on it a coif and a woman's dress. They hoisted this figure up on a long pole and, dancing and singing, carried it across the border of their village, borough or parish and tied it to the top of a tree in the woods. This was to mean that all mishaps and bad luck were over and that grain and flax were to give good yield in this year. In Germany, where a similar thing was done in the past, people said that they were taking away winter or death. (Eesti-ma rahva... 1838, Laakmann, Anderson 1934: 14, Laugaste 1963: 138-139).

The present paper deals with the custom of metsiku tegemine [making the Wild One, Estonian mets 'forest'], 1 i.e. a tradition of making a straw puppet, dressed as a man or a woman, which was carried out of the community territory on one of the yearly winter festivals of the folk calendar. The custom, known in several West Estonian parishes, was relatively well-documented already at the turn of the 17th century when it was described as a pagan rite of peasants. Later students of folk belief have treated the custom correspondingly as a cult rite and therefore metsik is often mentioned in respective surveys on Estonian folklore and mythology. However, the meaning of the custom has not been fully understood by researchers, as the "folk" attributed these activities a cluster of different meanings. To clarify the matter (to distinguish real tradition from "bare speculation") Walter Anderson in 1934 published all sources about metsik available to him (see Laakmann, Anderson 1934: 3-26). On the other hand, Anderson neither draw any final conclusions nor undertake to describe the history of the custom, leaving the task to future researchers (ibid.: 11). Subsequent folklorists and researchers of folk belief have formulated their positions on the issue but to date we do not have one dominant interpretation. It is rather the opposite, even after Anderson's source publication the claims of researchers have been unsettled, partially they lack solid support and frequently opinions tend to be based on earlier questionable interpretations (see e.g. Oinas 1992: 680, Troska 1995).

In Estonian popular tradition we can find other rituals similar to metsiku tegemine not mentioned by Anderson. In addition, there are numerous data about the respective customs of neighbouring peoples. After Anderson's source publication, no studies of Estonian folklorists specifically devoted to this custom have been published, and this is another reason to return to the problem.

In the present paper I will try to find answers to the questions of under which type of custom metsiku tegemine can be classified, what is its historical place in the context of Estonian folk belief, and what is the relation of the activity to other similar customs in Estonian popular calendar. Greatest attention will be paid to the meaning of these rites, to the explanations given to the custom in different places and at different times by tradition bearers, as well as to various interpretations given to the ritual by researchers. In the very end of the article (Chapter 4 ) will be presented some concluding remarks and hypotheses concerning the changes of the particular phenomenon during the period of three centuries. 
H. Laakmann's and W. Anderson's above-mentioned study Ein neues Dokument über den estnischen Metsik-Kultus aus dem Jahre 1680 (1934) will be used as a source of descriptions and accounts from the 17th and 18th century. For later texts, the materials of the Estonian Folklore Archives (EFA) in Estonian Literary Museum will be reffered to. In the case of published accounts, descriptions, and archival texts, the references include the parish of origin in brackets and the year it was recorded. In the list of archive sources at the end of the paper the references have been presented in accordance with the EFA's archiving system.

1.

Earlier accounts from the end of the 17th and the beginning of the 18th centuries concerning metsiku tegemine originated from Baltic-German ministers and officials who worked in Western Estonia (more precisely in Läänemaa and Pärnumaa counties): for example, the inspector of Virtsu Manor, Thomas Hiärne (1678); $\not 2$ the secretary who wrote the Audru Church visitation minutes (1680); the city alderman of Pärnu, Johann Günther Gerlach (1694); the minister of Karuse parish, H. M. Philipp (1693); the minister of Mihkli parish, Heinrich Göseken (1694); and the minister of Hanila parish, Erich Christian Weidenhain (1709)*3 (see Map no.1). The custom of Estonian peasants to make a straw puppet on autumn and winter calendar festivals and to organise a procession to carry it out of the territory of their village is mentioned in descriptions of peasant superstitions, in the minutes of church visitations and the ecclesiastical court, and in the ministers' responses to queries about "pagan assemblies". Thus knowledge about metsiku tegemine is most directly connected with the campaign of church visitation in Estonia at the end of the 17th century (see Kahk 1987: 162-164). These largely overlapping and complementary descriptions make it possible to conclude that the custom was well known in a narrow area on the Estonian West coast (in the parishes of Karuse, Hanila, Mihkli, Lihula, as well as in Audru and Pärnu). Gerlach's description from Pärnu parish (1680) points to the existence of a distinctly local tradition. According to this account, the peasants of the village of Lemmetsa of the parish of Pärnu claim that they did not know anything about metsiku tegemine before a man named Ralli Hans came over from Lihula parish after the death of his sister to supprt his sister's children (Laakmann, Anderson 1934: 4). It may be that in their communication with officials the peasants were not completely truthful, but it is yet more likely that in the parishes of Pärnu and Audru the custom was since unknown, and therefore the church authorities were informed of the new custom.

The aforementioned record of court proceedings (Pärnu 1680) is of great interest also for another reason as it contains two Estonian folk songs in traditional metre (regilaul). These are the earliest complete record of an Estonian folksong, the so-called "Nõelamängulaul" [Song of the Needle Game], *5 and a passage of the song which accompanied the procession of carrying the metsik (Laakmann, Anderson 1934: 10, Laugaste 1963: 229, see below). The most detailed description of the custom, however, was delivered by the minister of Hanila parish, Weidenhain (1709), in his letter to the Revaler Burgericht concerning "pagan assemblies", where it is pointed out that the figure of metsik was also called maakuningas [earth-king, king of the land]:

...und sollen Sie bey allerhand abergläubisch. wesen, den letzten feyertag im weynachten, einen von stroh gemachten abgott den Sie metzick, oder mahkunningas nennen, Ihn mit flachs vielerley garn, und andern dergleichen Sachen, wegen glück des fischfangs, und feldbaues bebinden, und verfertigen, auch gedachten abgott hierauff, mit Sack Pfeiffen, und Heydnischen liedern, auff einer frembden Herrschaffts land insgesambt begleiten, und bringen, der meinung daß dadurch alles unglück, von Ihrem lande ab, und auff das frembde landt gebracht werde, worauf Sie dan wieder 
mit groben Jauchtzen, frohlocken, und freuden, in selbiges gesinde, zurückekehren, und biß an die fasten hinan, oder auch wohl ehr, nachdem Sie vorraht an bier haben, alle Sonabend nacht gegen den Sontag zusammen bleiben, und Ihr heydnisches wesen weiter treiben...(Laakman, Anderson 1934: 13-14).

Archives and publications do not contain descriptions of metsiku tegemine from the following century. It is possible that the gap was caused by the epidemics which devastated Estonia at the end of the 17th and the beginning of the 18th centuries, by repeated famines and the Great Northern War. Namely the descriptions from the 17th century came from the time preceding the 1695-1697 famine which killed every fifth inhabitant of Estonia, and Weidenhain's 1709 account was written before the plague of 1710-1711, in which the population of Läänemaa and Hiiumaa counties was decreased by more than 3/4 (more precisely 77.3\%, Juhkam 1992: 389). On the other hand, it is possible that the tradition was abandoned due to the activities of the Moravians who were systematically combating manifestations of folk belief in Saaremaa and Läänemaa counties after the 1720s and 30s, and especially in the 1830s (Põldmäe 1935: 126-132, 1965: 207, 217).

In the 19th century, descriptions of metsiku tegemine can be found in the writings of Baltic-German scholars who, in the spirit of the Enlightenment, compiled surveys of Estonian popular culture. A comparison of these texts makes it possible to conclude that, for example, the description by J. C. Ph. Willigerod (1814: 11) coincides with Hiärne's text (1678). The first description in Estonian, published in J. H. Gressel's popular calendar (Eesti-ma rahva... 1838), was largely based on the account given by the minister Göseken from Mihkli parish (1694). The description was supplemented by the calendar editor's own knowledgeㅌ 6 and described metsiku tegemine as a pagan rite of Estonians dating back to the Swedish era (see motto above). It is not likely that this calendar text had a direct influence on the folk tradition, as there are no records of such stories being told in the oral tradition. However, the above description seems to be connected with the one conveyed by F. R. Kreutzwald, which also mentioned dressing up a puppet, one year in a man's and in the other year in a woman's clothes, as well as the fact that the puppet was called metsaisa [forest father] or metsaema [forest mother] (1854: 12, 81-82). The Kreutzwald's comment added to the description shows that, in comparison with accounts coming from the 17th and 18th centuries, his knowledge about metsiku tegemine was fairly vague and was grounded on secondary sources. According to Kreutzwald, the action was carried out in several places as late as at the end of the 18th century, and according to the only specific location given, recently several such figures were found in the forests of Vändra (ibid.). On the other hand, the folk authenticity of identification of metsik with the names for forest spirits (metsaisa and metsaema, see Loorits 1989 [1932], 58) is questionable and may also point to a secondary tradition. We can say that the idea of connecting the forest spirit tradition and metsiku tegemine starts with Kreutzwald, but it is very likely that it is purely his own scholarly interpretation.

F. J. Wiedemann's (1876: 353) conclusions on the matter are obviously also based on Göseken account (1694) and/or Gressel's calendar. He finds that the metsik is a forest god who changes its sex every year ("eine Waldgottheit, welche jährlich ihr Geschlecht wechelt"), and speculatively he compares the name metsik to metsahal'l'ijas [forest spirit] and metsa-ton't [forest bogy]. Such analogies are still no more than scholarly hypotheses supported by earlier scholars' interpretations since, apart from the names, Wiedemann does not mention any other common features.

According to J. B. Holzmayer, metsiku tegemine was known in Saaremaa in the parish of Kaarma in the middle of the 19th century. In addition to his description of the making of the figure and the procession, Holzmayer writes that the metsik is an evil spirit which could grant luck in cattleherding and which lived in the forest ("ein böser Geist, der über die Heerden und das Gedeihen des Viehes zu gebieten hat und im Walde lebt"), and to whom sacrifices were brought almost every day 
("fast am jedem Tage des Jahres wird er durch Opfer gebeten" Holzmayer 1872: 10-11). Nowhere else has the metsik been described in such a way and it is very likely that in this case other beliefs and notions have become intermingled with the making of the straw puppet. The broader semantic field of the word metsik is confirmed by other accounts recorded by Holzmayer, according to which it was something resembling a scarecrow attached to fences in out-of-the-way places to defend crops and herds; also metsik can have been used as a swear word (ibid.). Holzmayer was definitely familiar with the works of Kreutzwald and was probably aware of the minister Göseken's data that had been published by that time, as well as the description in Gressel's calendar. The motive of taking away the winter mentioned in the latter source was, according to Holzmayer, known also in Saaremaa, where a piece of wood wrapped in an old rag was taken to the forest so that the winter would go away and summer might come (Kaarma 1867).

In the 20th century, folklorists have obtained scarce data about the metsik only from Saaremaa. In 1930, Mihkel Soonlepp (b. 1858) from the village of Koikla told of the making of a metsik on the border between two villages in the parish of Karja. He called metsik the protector of the herd: it should have protected the cattle of both villages throughout summer against accidents and wild animals (Karja 1930). The speaker had not himself seen the making of a metsik but was able to show the place called metsiku mulk [opening of the metsik] between the villages of Koikla and Lepi where the action had been carried out. The form metsis has been recorded in the parishes of Karja (1926) and Mustjala (1938), but also in these cases the custom is known only through the accounts of older people.*7

Thus we can say that metsiku tegemine was first observed by researchers at the turn of the 17 th and 18th century when the tradition was alive in Western Estonia. Accounts and descriptions from the 19th century come from a wider area, but the custom seems to have been dying out or undergoing transformations. In the 20th century, the making of the metsik (or metsis) has been known only in Saaremaa. Similar customs are known elsewhere in Estonia, but they are called and explained differently. Below I consider different aspects of metsiku tegemine in greater detail and compare them to activities known from later periods.

What is common to all descriptions is the making of a straw figure and dressing it. Some accounts mention sexually distinctive features. According to the most detailed description of the figure found in the minutes of the ecclesiastical court of Pärnu it was approximately $75 \mathrm{~cm}$ tall and wore a black hat, and the hair showing from beneath the hat was made of tow which was also used for the beard. It had a sword made of a sliver of wood on its belt, with an erect penis protruding ("ein menlich glied vorn"), and it was possible to stand it on the floor or ground (Pärnu 1680). In the text mediated by Göseken it is mentioned that the figure was dressed in men's clothes one year and in women's clothes the next (Mihkli 1694, Eesti-ma rahva... 1838, Kreutzwald 1854: 81). According to account by Weidenhain (Hanila 1709), the figure was decorated with flax and other similar materials. Holzmayer's accounts mention making a straw puppet from a sheaf of straw and stuffing clothes with straw (Kaarma 1872b, a, Karja 1930).

Invariably something is done with the figure. Nearly all descriptions mention the border of a village (or community) and the crossing of this border. For instance, in the indictment in the Ralli Hans case it was pointed out that the figure was taken from defendants' own land in the village of Lemmetsa (Pärnu parish) to the fields of Audru parish (Audru 1680). A similar episode in which the metsik was carried is described by Weidenhain: the figure was taken collectively to the land of 
another landlord (Hanila 1709). In the 20th century, people have remembered making the metsik or metsis on the border between two villages (Karja 1926: 1930). Moreover, it appears from the descriptions that the figure was taken out of village and into the forest (or another out-of-the-way place, e.g. a pasture), and put on top of a tree (closest to the border) (Hanila 1678, Mihkli 1694, Kreutzwald 1854: 12, Kaarma 1872a, b, Mustjala 1939). It is characteristic that the figure was put (set, bound) and not hung on the top of the tree, as in earlier descriptions also the German verbs "setzen", "stellen", "binden" were used. In the majority of cases there is no information about the further fate of the figure. $* 8$ It is reasonable to suppose that the figure was left in the place to which it was taken and that there was no further interaction with it. In this respect, Holzmayer's information about daily sacrifices to the metsik and the various activities carried out in front of the figure stands out as an exception.

The necessity of making the figure of the metsik has been explained in various ways, good luck for the crops and the herd being two aims mentioned. According to early records, the figure was made in order to cause the grain, field crops and flax to grow and yield well ("das Korn, die Feldfrüchte, und das Flachß wol wachsen und geraten sollen" Mihkli 1694) or to protect the herd from wild animals and guard the borders of the land ("daß er ihr Viehe vor den wilden Thieren bewahren und ihre Grentze hütten solle" Hanila 1678). Similar explanations to the effect that such a ceremonial metsis was meant to protect the herds of the villages from wild animals throughout summer were later known also in Saaremaa (Karja 1926; also Kaarma 1872 a, b).

The minutes of the Ralli Hans' judical proceedings reflect the rationale of the activity in two ways. At the start of the minutes, the secretary points out that the case is based on a complaint according to which the accused carried the metsik out of his land in order to increase the blessing to his land ("Er einen Metzigk auf Ihr land gebracht, den Segen von ihrem Lande zunehmen" Pärnu 1680). This probably corresponds to the explanation given by the accused himself where he stated that the figure was carried out to the borders (of the village) in the hope of a better harvest ("hette den Metzick aus diesem Gesinde [---] an der Grentze gatragen, verhoffend ein beßer KornJahr zu bekommen" Pärnu 1680). In this formal complaint, however, the peasants of Audru accused the peasants of Lemmetsa of having made a straw man according to their custom, which they took to the fields of Audru and then left it there as a danger to the people and a dishonor to children and passers-by ("denselben hernach auf ihren der Auderschen Acker gebracht, und da, zu ihrer besorglichen Gefahr, Schmach und Ergebnis der Kinder und vorübergehenden stehenlassen" Audru 1680). A similar idea was expressed by children who participated in the activity which, as they say, took away their misfortune ("Sie, die Kinder, das Buschmänlein oder, wie Sie meinen, Ihr Unglück weggebracht" Pärnu 1680, see also Gressel's calendar). All of these reasons are represented in Weidenhain's account. He writes that the figure was decorated with flax and other similar materials in order to obtain blessings for the harvest and the catch of fish, and was sent to the lands of another landlord, in the belief that all of their misfortune would be thereby carried out of their land and brought into another land (see above, Hanila 1709).

Thus it is possible to distinguish two basic ways of expressing the reason behind this set of activities. It was emphasised that the making of the metsik served (1) to grant luck in harvest, catch and cattle, and protection for the entire land; on the other hand it was supposed that (2) along with the figure, misfortune was borne from one's own land to elsewhere. Weidenhain's account, which also mentions the secrecy of the activities and the difficulty of obtaining data (see Treumuth 1932: 18) makes it possible to conclude that the pursuit of luck is dominantly linked to the making of the figure - the dressing of it, the expression of its gendered characteristics and its decoration. The carrying of the figure out of one's "own land" is related to the exorcism of mishap. On the other side it is reasonable to deduce that the pursuit of luck or happiness for the self is carried out through the 
banishing of evil - i.e. the removal of the evil itself constitutes the greatest luck. On the basis of the descriptions, the removal of the metsik from one's territory can be seen as a type of exorcism used to promote the harvest and cattle growth and to obtain good fortune as such.

Many descriptions indicate that straw figures have been made and carried out of the borders of the community at different times. Thus nearly all of the accounts originating from the 17th or the 18th century mention the custom of metsiku tegemine in connection with assemblies of peasants in the so-called "game-rooms" (Estonian Mengitubbat, Mengitohhat, German Spielstuben) arranged on larger farms and in public houses on Saturday evenings throughout the period from Michaelmas Day to Shrove Tuesday. A contemporary account says that people went there to eat, drink, play, dance and enter into all kinds of frolic and frivolity ("fressen, sauffen, spielen, tantzen und allerhand Büberey und leichtfertigkeit treiben" Audru 1680). It is likely that this approach is exaggerated and biased. It is highly probable that in winter the "game-rooms" served as assembly and communication centres for both grown-ups and the younger generation.*9 Accounts also show that the metsik was made by the very people who gathered in the "game-rooms", and there are data which show that the figure was kept in a household for some time (Pärnu 1680, Karuse 1693, also Kreutzwald 1854: 81). Information concerning what happened to the figure inside is scarce. From a short complaint made by the minister Philipp we learn that the people were jumping around the metsik every Saturday night ("das Volk alle Sonnabends Nacht zusammen Komme hüpfe üm die Metzicks" Karuse 1693). However, even this statement can be interpreted as the rhetorical expression of a clergyman concerning behaviour he deemed inadmissible. Speculatively, we can also identify the festivals called metsa pidu [forest party] or metsiku pidu [metsik party] mentioned by Kreutzwald and Holzmayer with the "game-rooms". And it is very likely that Kreutzwald's statement in which such an event is referred to as a bacchanal, since the behaviour there was "scandalous and improper" (1854: 12-13), is just a guess or a hypothesis. Merry-making and free relationships were a part and parcel of the celebration of bigger folk holidays but were by no means accepted by contemporary Christian ethics.

Early sources say that the metsik was driven out of the village on one of the mid-winter_festivals which usually coincided with Christmas and the start of the season in which the "game-rooms" were not in use. According to the materials from the ecclesiastic court of Pärnu, the figure was taken out on a Sunday following Epiphany (January 6) (Pärnu 1680). The beginning of the New Year and the last holiday of Christmas, is also mentioned by Hiärne (Hanila 1678) and Weidenhain (Hanila 1709). It is characteristic of customs occuring near the New Year that the meanings attributed to particular activities are generalised and taken to have an influence on the whole of the subsequent year. The mention of the pursuit of a good catch (Hanila 1709) indicates that Weidenhain's information comes from a coastal parish. In pre-Reformation times, Shrove Tuesday has been the end date of winter assemblies which also signified the beginning of Lent. Göseken has mentioned metsiku tegemine as a custom of this day, and typically for Shrove Tuesday, the ritual was carried out in order to ensure a good flax harvest (Mihkli 1694). Shrove Tuesday is also noted in the latest accounts from Saaremaa (Karja 1930, Mustjala 1939).

However, at this point we also have Kreutzwald's record, according to which the metsik was made on Annunciation Day (March 25), whereas the figure was taken to the forest on a festival ("feierlichen Tage") when a metsa or metsiku pidu (see above) was held. Holzmayer quotes an account concerning the making and removal of the figure on a date determined by the elder of the village ("Aeltesten des Dorfes wird ein Tag bestimmt" Kaarma 1872a). According to information recorded in Karja parish in 1926, metsis was made every spring before turning the cattle out to pasture (Karja 1926). The day can be compared to the traditional date of letting the cows out to pasture (April 1), and it is quite natural, since metsiku tegemine in Saaremaa has always been connected with the protection of the herd. 
It is remarkable that according to both earlier accounts and later descriptions from Saaremaa, the ritual was not connected to any specific date. The lack of regimentation and the fact that the activities were not carried out on certain calendar festival but the date was determined by the village community, can be viewed as archaic traits (cf. koräädsi praasnik of the Setus, Hagu 1974: 166). On the other hand, the variation in dates points to differences in local traditions and the possibility that the custom did not become rooted in the Estonian folk tradition.

The ceremonial nature of metsiku tegemine was stressed in songs and tunes played on the bagpipe. In the minutes of the ecclesiastical court of Pärnu (1680) it is written that Tõnis, the cousin of Ralli Hans, carried a straw man to the border of the village and accompanied the procedure on a bagpipe; when the figure was taken away, a song was presented, of which three verses were preserved in the minutes:

\begin{tabular}{|ll}
\hline Hölline Mötsa öllada & The straw one has forest to live in \\
Metzike mötsa minneda & The wild one has forest to go in \\
Sarra uße satada. & A hazel wood to be sent into.*10
\end{tabular}

This is a specific song which has accompanied the ritual and as such it is comparable to songs sung on Shrove Tuesday, St. Catherine's Day and St. Martin's Day. In 1939, Marta Lepp in Mustjala parish said that her mother had spoken of taking the metsis into the forest adding that the procedure was accompanied by the song Metsist metsa viiakse [Themetsis is taken to the forest] (Mustjala 1939). There are no other known variants of the song, but singing and music are mentioned in other early accounts. Minister Weidenhain wrote that the metsik was sent into a strange territory accompanied by bagpipe music*11 and pagan songs, and after this the crowd returned to the "game-room" for carousing and merrymaking (see above, Hanila 1709). This parallels a description from Gressel's calendar. According to Hiärne, all the villagers took part in carrying out of the figure (Hanila 1678); Holzmayer's description states that the procession of the metsik was conducted by the village elder (Kaarma 1872). Thus metsiku tegemine has been a public and ceremonial undertaking conducted by large groups of people.

Contemporaries wrote that metsiku tegemine was a pagan ritual - in relevant records the Estonian names Metziko, Metzigk, Metzick, Metzik and mahkunningas are used alongside German terms probably expressing the views of the recorders ("Buschmänlein", "Götzen", "Götzen von Stroh", "Mann von Stroh", "abgott" etc.). Remembering the witch hunt of the 17th century Estonia (see Madar 1987) and the "romanticism" of the scholars of the 19th century, the emphasised ritualistic nature of the event could be considered an exaggeration. According to the most detailed description available in the minutes of the ecclesiastical court of Pärnu (1680), children assembled in "gamerooms", jointly made the figure and then took it out. Thus it can be supposed that also in this case, people themselves saw the activity as part of children's New Year's buffoonery which had no "serious" magical, let alone cult, meaning. The activity caused trouble because the custom was unknown to the people of the neighbouring village, it was treated as witchcraft, harmful and dangerous magic, and authorities were informed (see Audru 1680). Here it is possible to see reflections of the George Foster's notion of 'limited good' according to which one's good fortune can only be obtained at the expense of the bad fortune of others (see Oinas 1992: 679).

At this point we come to the question about the role of the name of the straw puppet, metsik [the wild one]. Does this meaning refer to the fact that the figure was taken to the forest, to its 
connection to the woods in a figurative sense, or can the explanation be found in meanings no longer present in the language? Estonian lexicography has paraphrased the word metsik as 'forest, thicket', 'coppice' and also as 'wild boar' (Saareste 1958: col. 642-643, 1959: col. 880). A dictionary of Standard Estonian gives the following adjectival meanings of the word: 1. 'sth. manifest in its natural (primeval, primitive) form', 2. 'uncivilised or undeveloped', 3. 'wanton, intemperate, crazy, cruel, crude', 4. 'immense, stupendous, monstrous' (EKS 1994: 423-424). Here it is important to note the opposition between "the cultured" and "the uncultured" which may be expandable to the oppositions of "own" - "alien" and "believer" - "unbeliever". It is likely that this is the basis for the Orthodox Setus' use of the word mõtsik for a neighbouring people of a different faith (Lutherans) and that in South-Estonia the word has been used as a parallel name for the Devil (Loorits 1951: 100). In such a transfer of meaning, the term metsik (mõtsik) initially designated 'an alien', 'a person of different faith', and later it became a name for the Devil.

It is possible to propose a different sequence of semantic shifts which presupposes the existence of some early specific religious meaning of the word. According to Mägiste (1927: 74) the word mets [forest], especially when complemented by several suffixes or endings, has yielded swearwords with meanings closely connected to the devil in nearly all Balto-Finnic languages. Pointing to the chain of transfer "forest spirit $>$ devil $>$ swearword" he offers South-Estonian mõtsaline and mõtsik as examples. Thus we may presume that mõtsik as a mythological entity has been demonised in South Estonia and subsequently the name of devil has been used for people of different faith. On the other hand it is not very likely that the straw figure was initially carried to the forest for a forest spirit or that it was an impersonation of such supernatural being (see Eisen 1995 [1919]), and we cannot confirm the validity of this model of transfer. Thus the explanation of the term metsik probably lies elsewhere.

The most intriguing is the name maakuningas [earth-king, king of the land] mentioned in Weidenhain's description in parallel with metsik. Taking into account parallels from the Estonian settlers in Russia, so-called Kraasna people (see külä-käü kuningakane [king of the village], Kallas 1903: 79-80), the name might point to beliefs connected with earth spirits and indirectly to the area of meanings connected with fertility. This connection is but a hypothesis and it is possible that such usage has been unintentional, jocular or metaphorical. It is the view of the author that it is too farfetched to interpret metsiku tegemine as a cult of fertility spirits and to claim that the metsik was a puppet-shaped idol of fertility made of straw (EE 1935: col. 1196), a fertility spirit or that the spirit was impersonated by a figure made of straw (see Oinas 1992, Troska 1995). Researchers have been inclined to accept such arguments also due to the emphasis on the sexual characteristics of the metsik in early descriptions (and the annual intermittent dressing of the figure in women's and men's clothes). However, there is no sufficient justification for drawing parallels between metsiku tegemine and fertility gods and goddesses with large sexual organs, androgynous or transsexual spiritual creatures (see Paulson 1997 [1966], 91-92).*12 In fact, descriptions (with the exception of the relatively more recent account by Holzmayer) do not indicate that any cult worship would have been associated with making the straw figure. In other words, the sources do not provide sufficient evidence to support the hypothesis that the straw figure was considered a figure of a guardian spirit or a god/goddess. The same applies to the interpretation of the activity as primarily a fertility cult since this presumption is supported enough neither by the subsequent records of Estonian folklore (see below) nor by the folk traditions of the other European countries. It seems that the crucial factor was the magical moment of the activity wherein all hostile forces that could have afflicted luck with the herd or crops were taken out of the territory (see Laugaste 1963: 62, Valk 1986: 73). Thus also in this connection, the word metsik could have signified something hostile or impure which was to be disposed of. 
There is an affluence of parallels between the custom known in West Estonia and Germanic and Slavonic tradition connected with festivals marking the arrival of spring (Shrove Tuesday, Lenten holidays) (see e.g. Waronen 1898: 265, Frazer 1983 [1923]: 286-295, Haavio 1932: 41-42, Propp 1963: 68-99, Kalendarnyje... 1977: 94, 98-99, 144, 194-195, 180, 205, 207, 228-230, 340-342, Dömötör 1989: 29, also Västrik 1993). The preparation of a straw figure or a puppet dressed as a man, its removal from the territory of the community in the context of a procession, followed by drowning, burning, burial or dismemberment of the figure has been interpreted as the exorcism of something bad, dangerous and harmful (e.g. death, disease, witches, winter). The earliest known description of the custom as practised in Europe comes from the year 1366. In that year the synod in Prague forbade priests to participate in the procession of carrying out the death (mors) (Kalendarnyje... 1977: 342). The roots of this activity definitely extend further into the past and we can point to an analogy with the phenomenon of the so-called scapegoat.*13 It is not unexpected that the custom in West Estonia in the Swedish Era is first and foremost connected with this pan-European tradition. Although there is no information concerning possible ceremonial destruction (burning, drowning, dismemberment) of the figure, the placing of the figure in the top of the tree may be a specific feature of Estonian tradition.

Thus, to sum up, in the 17 th and 18 th centuries, and probably also later, metsiku tegemine was a ceremonial activity undertaken in the interval between Michaelmas Day and Shrove Tuesday at assemblies (of the youth) in certain households (in "game-rooms") on Saturday evenings. Descriptions pay most attention to the transportation of the figure out of the territory of the community near the New Year or on Shrove Tuesday and it has been interpreted as the exorcist magic and removal of misfortune. The interpretations attributed to the activity predominantly point to the pursuit of general luck (crops, herding, fishing) directly connected with the removal of misfortune. The name metsik seems to be inexplicable - the most conspicuous semantic association of the word is 'uncivilised' or 'impure'. The only data concerning metsiku tegemine came from West Estonia and thus the custom seems to be an Estonian variant of exorcist activities spread throughout Europe.

Estonian Folklore Archives (EFA) contain descriptions of several other customs kindred to metsiku tegemine that are part of the set of customs associated with the above-mentioned holidays: Christmas, New-Year, Shrove Tuesday, and Ash Wednesday. A common feature of these customs is the preparation of a straw figure and its removal from the territory of the village (farm, family) with greater or lesser ceremony and also a negative meaning attributed to the figure.

\section{1 .}

The Shrove-tide custom of kadaajamine (also kaja-, kaeaajamine [driving out of rag(s)?]), practised at the end of the 19th century and the beginning of the 20th in West Estonia, the parishes of Hanila, Karuse, Kirbla and Mihkli (see Map no.2), can be seen as a direct corollary of metsiku tegemine. The calendar files of EFA include 15 accounts of the custom. The earliest descriptions originate from the end of the 19th century and the most recent from the 1970s (most of the texts have been published in Laakmann, Anderson 1934: 26-31, and in Lätt 1970: 121-122). For example:

On Shrove Tuesday a kada was made of straw and old rags, i. e. a figure of man was put on the top of a pole which someone then carried on his back and others were following him singing and beating with sticks. The kada was driven to the lands of another landlord and left there. It was accompanied by singing: 
Where do we take this kada,

To the woods and lands of Matsalu Manor,

To the pastures of Matsalu Manor,

To the houses behind the Kangru household,

And to the hearth of Korjuse Mart's household.

(It was a long song, it is now forgotten, same as the kada-cult is scarcely remembered by the elderly people.) From Puantse village the kada was driven to Järise or Pihama villages. (Karuse 1924).

Kada has been described as a figure of a man made of straw and old rags (Karuse 1929a), old trousers stuffed with chaff (Karuse 1929d) or as a piece of wood covered with tattered rags (Hanila 1936).*14 According to other accounts, the kada did not always resemble a man and was a loose structure or ball: for example, a bundle of rags, hair and junk (Karuse 1889a), old rags, mops of tow, etc. wrapped into a ball (Karuse 1889b), all kinds of rags put into a woman's skirt (Hanila 1890), an egg made of frozen manure or something like that (Mihkli 1894), a horse droppings in an old vessel (Kirbla 1936b) or bundle of rags in a basket (Hanila 1968).

Kada was carried on someone's back, it was poked with sticks, rolled on the ground and/or kicked at. As with metsiku tegemine, the activity was accompanied by songs mentioning particular places to which the kada was driven and emphasising that the kada was taken far away. Although the song texts point out that kada was taken to dwellings of others, this fact is not quoted in the descriptions of customs. The records dating back to the 1880s lay stress on carrying the figure to a strange land (field) and leaving it there: for example, the kada was driven through the snow with sticks and poles over the border of the parish; there poles were erected and the kada was put on them. Should the kada have been found there, the men of the neighbouring parish took it back to where it was brought from (Karuse 1889b). In 9 of the 15 accounts it was recorded that the kada was taken to the land of another (the third or different) landlord. 15

Descriptions from the 19th century show that for the participants, kadaajamine was a serious business. If unfamiliar kada drivers were seen or met on one's own land, a major conflict followed (Karuse 1889a, Hanila 1890, Mihkli 1894). Usually the kada was driven by the people of one village: it was noted that this was jointly done by old women, men, young girls or children. Accounts from the 1920s describe the activity as a children's game or pastime which points to the disappearance of the custom from active tradition at the end of the 19th century.

In the dialects of the Estonian islands, kada means 'a rag' and occasionally (in the parishes of Varbla, Järva-Madise, Kodavere, and Põltsamaa) 'a ball' (VMS 1980: 150). Taking as his point of departure the similarity between kadaajamine and the game of cudgels (kurn), P. Ariste included kada in Estonian-Swedish loanwords: kada < Estonian-Swedish katabol 'rag ball used in the game of kurn' (Päss 1931: 39, Ariste 1933: 59). On the other hand the etymology of the Swedish term kata is itself vague (Loorits 1951: 94). We can claim, however, that most of words having the kada stem in dialects have a prejorative shade of meaning: for example, kadal 'shabby, paltry', kadamus, kadaras, kadasnik, kadjakas 'ragged', kadron 'rag', also kadu 'revenant', etc. (VMS 1980: 150). In people's minds, kadaajamine has been predominantly associated with driving away something unpleasant. The effect of the activity has been described as follows:

(a) should drive weeds off the field (Mihkli 1894),

then the wrath of the forest would disappear from their border (Karuse 1889a),

thereby wolves were driven away (Karuse 1929b),

then wolves would not touch the herd of the village (Karuse 1889b),

so that wolves would not kill the herd (Karuse 1929a), 
(b) wolves' evil doings and diseases of the herd were driven out to another village (Hanila 1896), so the wrath of the landlord would befall the land of another landlord(Hanila 1936), so wolves will kill more cattle on that land (Kirbla 1936b),

(c) then the flax will grow well (Kirbla 1936a), then the flax will yield (Hanila 1968).

The reasons display obvious parallels with metsiku tegemine. The meanings attributed to kadaajamine are dominated by the idea of deterring something unfavourable, be it wolves (= the wrath of the forest), cattle disease, weeds, etc. The main emphasis is put on the protection of the herd, although it is not dominant in Shrove-tide rites. In keeping with the character of Shrove Tuesday some descriptions note the hope for a good flax harvest; such explanations, however, occur only in the later accounts.

It is noteworthy that Shrove-tide customs include other types of exorcism: for example, the driving of "pigs" practised on Muhu Island where the children drove round wooden platters out to the field with sticks so that the pigs would thrive in the fields during the summer. In the southern parishes of Viljandimaa and Pärnumaa counties the custom named vastla kottiajamine [driving a personified Shrove into bag] was practised on the same day. The activity was meant to make fun of the children and at the same time it meant a driving an imaginary personified Shrove out of the hayloft by shouting and pouring water down from the barn attic (for examples and explanations see Lätt 1970: 113-114, 122-124, 131, 133).

\section{2 .}

The preparation of clothed straw figures was also practised during Christmas and New Year in the interval between St. Thomas's Day (December 21) and Epiphany (January 6). During this period of time, particular attention was paid to straw. Straw was used to prepare decorations, hats and figures of animals and men which were then used for both games and rituals (see Eisen 1931a, 1932b: 1226, Hiiemäe 1995: 13, 49-58). We will now discuss accounts which mention dressing the figure and taking it somewhere and/or the meanings attributed to these activities. The author is aware of 66 descriptions, the earliest of which come from M. J. Eisen's folklore collection in the EFA from the beginning of the 20th century. The most recent were collected during fieldwork trips carried out in the 1990s in the parishes of Pilistvere (1993) and Kullamaa (1997) (a few of these accounts have been published in Hiiemäe 1995: 13, 20-21, 133-136; see Map no.3).

Regionally, these straw puppets received different names. The most frequent names were TahmaToomas [Ash Thomas], nääritont [New Year bogey] and nääripoiss [New Year boy] (Harjumaa, Läänemaa, Saaremaa counties), but also the names jõulutaat [Christmas father], jouluvana [Christmas elder], Jõulu-Toomas [Christmas Thomas], näärijäär [New Year ram], näärimees [New Year man], näärinokk [New Year beak?], näärinäkk [New Year water-nymph], näärisokk [New Year goat], nääritaat [New Year father], tahmatont [ash bogey], uueaastapoiss [New Year boy], etc. There are also numerous descriptions of people making straw or rag figures, babies or dolls whose specific names have not been mentioned. Occasionally the same account referred to the straw figure using different names or it was mentioned that different names were used simultaneously.

Most accounts concerning the making of the figures at this time came from the parish of Juuru (23 of 66). In Juuru, the custom was viable for a longer time than in the neighbouring parishes - the rite was carried out in Orguse and Härküla villages as late as 1987 (Juuru 1987e, g).*16 In 1929, the making of the New Year's figure was described as follows: 
A figure of a man - Tahma-Toomas [Ash Thomas] - is made of straw and old clothes and taken on New Year's Eve to someone's yard. The man has a letter in his pocket: my name is Tahma-Toomas. No one wants to have him in his yard by the morning, but takes the man to the neighbour's yard. This is done to spite others. Once neighbours really started quarrelling and started throwing the figure over the fence until it was all tattered. The household in whose yard Tahma-Toomas is left by morning will not be able to work properly in the new year and their house will be dirty. When I was a child it was not done. Younger people started doing it. Tahma-Toomas or nääritaat [New Year father] or jõuluvana [Christmas elder]. (Juuru 1929c).

Another area from which there are more recorded data on the making of figures, and where the custom has survived longer, is the parish of Kullamaa in Läänemaa county. For example:

And the old bandyleg was then made of straw, this was to be the great tahmatont [ash bogey]. And then it was taken to the door of another household so that when the family got up early in the morning and found it there, they should have laziness and suchlike in their house. The straw boy: then a wisp of straw was just strung together and hands somehow put on it and feet twined under it and one wisp put on the head and it was ready. This was done even in the year 1938-39, even in the 1940s. It was also done farther away, but Liisa from Mätiku household made it in front of the sauna of Jõesuu. In the sauna people were very quick and took it away to the household of Hiie. The ash bogey then travelled. But this was only until the 1940s, after the war I don't remember it any more. (Kullamaa 1990c).

The New Year's figure was made of straw and old rags: for example, straw was put around a frame so that it resembled a person, and an old threshing hat was put on its head (Kullamaa 1937), it was made of old threshing clothes with a pole for hands (Juuru 1929f). The figure was also twisted from chaff, with three legs so that it would stand upright (Kullamaa 1990b, dominant in West Estonia). Most accounts were about the stuffing of (threshing) clothes: for example, trousers and a shirt were stuffed with straw, an old hat was put on its head (Äksi 1961c), chaff into a sack and men's trousers on it, in some places it had a hat on its head and in some cases a scarf, all the same if it was made into a man or a woman, a dark sack for a head, eyes drawn with coal, eyes and nose - a bulgy one cotton was put into it (Pilistvere 1993a), or old trousers and a coat full of chaff, joined with sticks so that it would stand upright (Hageri 1936).

In some descriptions it was stressed that the figure was smeared with soot: for example, they took an oven broom, an old back support from a sledge and a ragbag smeared with soot and dust (Võnnu 1896). Also the figure might have a pipe in his mouth or some other valuable hidden inside it which would be a gift for the recipient (Märjamaa 1929). In general the sex of the figure was not noted in the descriptions. According to couple of accounts Tahma-Toomas had a carrot for genitals and turnips for testicles (Juuru 1934). Also the figure was in more recent time provided with a letter containing an explanation: for example, I am Tahma-Toomas [Ash Thomas] (Juuru 1929d), Kratt [supernatural wealth bringer] (Pilistvere 1993a), etc.*17

Usually the figure was taken secretly to another household and put on the door or window. It seems that the greatest importance was attached to taking the New Year's figure to a place where the neighbour would see it, and not to carrying the figure off of one's own land. The recipient of the figure might be specified in greater detail: often these figures were taken to the doors of girls by boys (Märjamaa 1923, also Kose 1936, Kullamaa 1990a, Pilistvere 1993b) but the custom was also practised the other way round. Sometimes the activity has been described as a mutual "settling of accounts" between boys and girls. A similar method was used to "earmark" and ridicule social anomalies, e.g. bachelors and spinsters (Vändra 1988a), or people who were elderly or mean (Kullamaa 1990c). 
No one wanted to keep the New Year's figure and it was taken further, which was explained as taking the straw figure from one household to another. The descriptions did not specify what happened to the figure in the household where it was finally left. It was said, for example, that the figure passed through the whole parish before it was burned (Vändra 1935) or someone threw it away (Juuru 1987a). Sources from Kullamaa parish indicate that the straw figure was beaten while the head of the household chanted: go away, so that you will not take away our boys' Christmas! (Kullamaa 1937, also 1990a). In Võnnu parish it has been recorded that Tahma-Toomas was put into a hole dug for that particular purpose (Võnnu 1896).

The negative meaning of the activity was universally known. It was said that the straw figure was carried around by those in the habit of teasing their neighbours on New Year's Eve (Türi 1966), or that it was done to spite the neighbours (Juuru 1929d), and to wish ill fortune and to have fun (Kullamaa 1960). The receipt of the figure carried such a powerful meaning that people were said to have stayed up all night in order to avoid being left with the figure in the morning. There are accounts saying that when the bringer of Tahma-Toomas was caught red-handed, his eyes were smeared with soot, a pole was put through the sleeves of his coat, and he was sent back home (Juuru 1929a, Jüri 1929).

The records do not stress the expulsion or exorcism of evil. The emphasis seems to be on the consequences that followed when the figure was not taken away from one's own household. The following are excerpts explaining the meaning of the figure, the accompanying activity, or the situation which resulted from keeping the figure in the household:

(a) it was bad there (Juuru 1929c), it did not bode well (Juuru 1987d), everything will not go well this year (Juuru 1987b), there was to be some trouble (Juuru 1934), some trouble is going to be there (Juuru 1987c), it means sheep plague on the farm (Kullamaa 1960), it takes away luck, the growth of household property or yield of crops (Kullamaa 1990c),

(b) it had a bad meaning, it meant dirt (Juuru 1929g), it's dirty there (Juuru 1987h), the household is dirty throughout the year (Juuru 1929a), there dirt will stay in the house (Juuru 1987f), there dirt will rule (Juuru 1929b), there dirt and disorder will rule throughout the year (Pöide 1947), there the family will be in a slovenly way (Juuru 1987e), people there are dirty and slovenly (Juuru 1928-1930), there the New Year's chores are neglected and dirt is in the house (Juuru 1929d),

(c) this one was considered to be lazy (Vändra 1988b), then girls are lazy (Pilistvere 1993b), there all the work has to be done by others (Paide 1929), there the family was to be the laziest throughout the year (Äksi 1961c), it was supposed to mean that they are very lazy throughout the year (Nõo 1961), then the family was to have laziness and suchlike in the house (Kullamaa 1990c), the people of this house are said to be lazy and slovenly (Hageri 1936), there the family was to be lazy and slovenly throughout the year (Äksi 1961b), these were to be the most lazy and slovenly (Juuru 1987i), 
(d) these [women] will bear a child this year (Märjamaa 1923, 1929),

this will become a girl with a child (Kose 1929),

these [women] will never get married (Kullamaa 1990a),

there a girl will never get married (Juuru 1987g),

there the daughter was not to get married (Juuru 1987c),

they stayed bachelors (Juuru 1987a),

(e) this meant a bridegroom for the girl of the household (Juuru 1929g),

when it is taken to the door of the landlord, it will mean good luck and giving birth to a son

(Märjamaa 1929),

when it was found before the morning, it meant good luck with sheep (Kullamaa 1960).

The latter passages (e) offer a better evaluation of the receipt of the figure, but these "reversed" considerations occur in parallel with conventional ones. Thus in the record from Juuru parish (1929g) we find both good and evil meanings. According to another description (Märjamaa 1929), the meaning of the figure was dependent on the recipient. On the other hand it could also depend on whether the figure was discovered before morning or not (Kullamaa 1960). Such ambivalent attitudes could have been caused by different interpretations given to the activity by the original village inhabitants and newly-arrived immigrants.

Although the exact wordings of the accounts are fairly different, we can see that majority of the accounts can be accommodated within the same semantic field: it was undesirable to leave the figure in one's own territory and was to be avoided, otherwise something unfortunate would follow the possession of the figure. Furthermore, dirt is a result of laziness and sloppy ways and either of these characteristics was sufficient cause for ending up a spinster or a bachelor. Remaining unmarried was, on the other hand, an misfortune comparable to unwanted pregnancy.

As we are dealing with a case of New Year's magic, all supposed consequences concerned the whole of the year to follow. According to some earlier accounts, Tahma-Toomas was made and carried about on St. Thomas's Day or on Christmas Eve (see Hiiemäe 1995: 13, 133-136). In most cases the figure was made and carried around on New Year's Eve. There is a traditional understanding: "As on this day, so for the rest of the year".

It is possible to point to a connection between this activity and other customs of Christmas and New Year. In the Estonian folk tradition at the end of the 19th century, St. Thomas's Day was a day of cleaning before Christmas and carrying out Tahma-Toomas (also Must-Toomas [Black Thomas], Tolmu-Toomas [Dust Thomas] and Nõgi-Toomas [Soot Thomas]) meant sweeping the barn oven and chimney or a major cleaning effort (records in EFA calendar files from the end of the 19th and the beginning of the 20th century from all over Estonian, especially in Viljandimaa and Tartumaa counties; Hiiemäe 1995: 12-13, 32-34). In Saaremaa county a sheaf of grain retained from the harvest was brought inside (põllupõrsas [field pig], kollivihk [bogey's sheaf], tulupoiss [boy of profit?], rehepapp [treshing barn's priest]) and Christmas foods and drinks were ceremonially served (Ränk 1949: 194).

\section{3 .}

In the southern parishes of Pärnumaa and Viljandimaa counties the preparation and transportation of straw and rag puppets have been a part of the customs connected with Ash Wednesday. The figure was usually called tuh(k)apoiss [ash boy], as well as tuhkapuss [ash bag?], tuhamees [ash man], tuh(k)atüdruk, tuhkapreili [both: ash girl], tuhakott [ash bag], etc. The Estonian Folklore 
Archives contain over 90 records of the custom, the earliest of which originate from the 1920s, whereas a large majority of the accounts have been recorded in the 1960s (mainly in the parishes of Karksi, Helme, Paistu, Halliste and Tarvastu; see Map no.4; some of the texts have been published in Lätt 1970: 142-143). The custom was definitely known at the end of the 19th century and survived up to the mid-1930s. Archival data indicate that the custom of making the tuhkapoiss was practised as late as 1957, when the figure with a note on its neck saying "I am lazy and looking for a job" was taken to the office of the agricultural commune (Helme 1962c). It is likely that the tradition survived even longer, as the descriptions of the custom are mostly based on personal experiences. For example:

On Ash Wednesday a tuhkapoiss [ash boy] was made: a cross of straw with a head on it and a small bag with ashes on its neck. Bigger ones made bigger puppets, boys made boys and took them to girls, girls in their turn made girls for boys. Once the tuhkapoiss was put high on the roof and no one could get at it. Then there was wailing for a long time. Sometimes a letter was put with it: this is your bride and you have to take her. Such letters were put with girls when they were taken to boys. (Karksi 1960m).

These figures were made similarly to the figures of New Year's Eve (cf. above): for example, it was made of straw and dressed (Helme 1934a), a bag of chaff was put on a stick and dressed as a boy or a girl, and a hat was put on it (Karksi 1933). The difference was in the filling of the figure and its head with ashes. The head of the tuhkapoiss was often made of a bag of ashes, or there was a bag of ashes fastened to the hand of the figure. 18 The sex of the figure was determined when it was made: when a man is made, there are two limbs at the bottom end, when a girl is made, it is with a skirt (Helme 1934c).

In some cases where the figure had a definite meaning, it carried a letter and a bottle of vodka, also a scourge, a club, a pipe, etc. The letter said who it was and what it wanted, for example: the ash boy wants to go to another household (Halliste 1934), is looking for a new place to live in (Helme 1936), is looking for a place to spend the night and half a bed (Karksi 1960f), is coming for betrothal (Paistu 1937), or that the old Kärt the Scabhead has come over (Karksi 1936), Miss Jungermann has come to woo Märt (Helme 1934b).

In the 20th century, the activity was carried out by young people or children. The figure was taken to the neighbourhood of another household secretly, so that no one would see it. In most cases, the addressee has been indicated and according to most records the figure was taken to households containing young people. For example, a boy was made and taken to where the girls were; a girl was made and taken where the boy was (Helme 1962a). The figure was put just outside/inside the door, attached to the door, thrown into the front room, into living quarters, onto the table or even into someone's bed. The action may have had a deliberately exaggerated character, for example: once the tuhkapoiss was tied to the chimney (Karksi 1960m), and in 1933 a figure was said to have been on top of a well bump on the market square at Abja village (Halliste 1934).

Often the taking of the tuhkapoiss was described as a guessing game and the family who had it tried to guess where it came from and take it back. Therefore the tuhkapoiss was carried to and fro for a couple of days, two or three weeks or even a whole month until someone destroyed it or carried the figure out of public sight. The destruction of the figure was never an aim in itself but rather the result of an urgent and sincere wish to find a way of getting rid of it: for example, the head of the household burnt it in the oven as he was superstitious (Paistu 1944), the gamekeeper shot it to shreds (Helme 1934b), one was taken and put onto a sledge, on the way it was tied to the top of a tree (Karksi 1960e).

Older people interpreted this custom as a destructive sorcery. People were afraid of receiving the 
figure, and conflicts arose because the tuhkapoiss was carried to another household. In nineteen texts the causal link has been presented more or less explicitly:

(a) the ash boy was taken around the households to bring bad luck (Karksi 1936), was always said to bring bad luck, people were afraid of it (Paistu 1944), who could not take it (further) had bad luck (Maarja-Magdaleena 1981),

(b) was a symbol of laziness (Karksi 1960g), meant laziness (Karksi 1960i), no one wants to leave it, laziness, at their place (Karksi 1960d), it was ordered that it be taken away, it was said: laziness get out of the house! (Karksi 1960j),

it was taken to someone else's yard in order to take away laziness (Karksi 1960e), one woman got very angry as she thought that we brought laziness to her (Karksi 1935b), it was said that "ash work" was brought; whoever was left with it would have a lot of work that year, and that the devil distributed duties on Ash Wednesday (Helme 1934a), the household where it is left will not have energy to work (Helme 1934b), whomever it is left with at dawn is lazy and has to take it away quickly (Karksi 1934), so as not to be thought of as lazy, people tried to take it further away from themselves (Karksi 1960h), whosever doorstep it is found by morning will become lazy for the next year (Karksi 1935a), where it was left in the morning there it was to be dirty throughout the year (Paistu 1946), those who took it away are hard-working people, and those who had it with them in the morning were lazy (Halliste 1940),

(c) some have said that from that household one will never get married (Karksi 1960d), it is a sign of remaining a spinster (Paistu 1930), in the household to where it was taken, the girls were to get married (Karksi 1960a),

(d) whoever was left with it was laughed at (Helme 1962b).

The dominant aspect in these records is laziness. This is not surprising, since other magic procedures for getting rid of laziness were also used on Ash Wendesday. The custom of making the tuhkapoiss was practised in the season when people were making preparations for the period of intensive summer work, and thus the magic-related desire for efficiency in work and the exorcism of laziness were topical (Lätt 1970: 137). There are data from Saaremaa and Hiiumaa concerning the custom of driving supernatural laziness out of the living quarters. For example, on Ash Wednesday the person who stayed up longest became tuhkatuss [ash arse?]. Tuhkatuss had to clean the rooms and sing: "Tuss, tuss, tuss, get out of the room, let the new work force replace you!" (ibid.: 140).

According to some of the examples (b, d) the figure was not inherently bad, but if it was left in one's possession, it made one lazy (bad, dirty, etc.) in the eyes of the others. For children and young people, as was frequently stressed in later accounts, the activity was a joke: it was said that jests were made that way (Paistu 1937), it was done as a trick (Helme 1962d), when someone wanted to tease or make fun of others (Halliste 1960). At the same time, the activity has its place in the relationships between young persons. According to one fifth of the records, boys made "gallants" for girls and girls made "sweethearts" for boys. Tricks were also played to emphasise something unusual or indecent, for example: once an ash girl was taken to two bachelors (Helme 1934b), a figure resemblant of a child was taken to people who had no children and who had lived together for a long time or it was taken to girls who were thought to have given birth to a child and then killed it, then the figure was put up on a pole for other people to see (Tarvastu 1940). 
Despite the playful nature of the activity, it has been mentioned that when the person who brought the figure was caught his/her arse was stuffed with snow and he/she was given a good beating (Helme 1934b), a broomstick was put through his/her sleeves so that he/she could not move his/her hands, the tuhkapoiss was bound to his/her back and he/she was sent home like that (Helme 1939) or that he/she was locked up in the pigsty (Karksi 1960c). In 1930s, the matter reached a court of law by mistake: the police caught the children who had carried the figure to a neighbouring household and their uncle had to go to court, since the police did not understand that it was a popular joke (Karksi 19601).

\section{4.}

In conclusion, we must consider the connections between different ways of making and carrying these anthropomorphic clothed straw figures. There is undoubtedly a genetic link between metsiku tegemine and kadaajamine, as both customs were known in the same parishes, although at different times. Again, although the areas in which the customs were spread differed, metsiku tegemine and making the figures at Christmas, New Year's Eve (Tahma-Toomas, nääripoiss, etc.) and on Ash Wednesday (tuhkapoiss, etc.) are connected through the traditional festivals of the popular calendar. According to data available from the Estonian Folklore Archives, these customs became known in Estonian folk tradition only in the 20th century. This occured either spontaneously or due to the cultural influences not known to author, whereas a traditional "framework" or "background" has always been indigenously present. In addition, it is possible that these customs were known in the folk tradition earlier, but are not reflected in folklore collections.

All above mentioned activities have similar structure which makes it possible to view them as different surface manifestations of one and the same phenomenon based on an identical or similar cognitive and behavioural archetype. The common feature was the removal and exorcism of something unpleasant by the transportation of a man-shaped puppet to alien territory.

One difference lies in the places to which the figure was taken: the ritual has been described as taking the figure to the forest (metsik), to a strange land/territory (metsik, kada), or to the yard or rooms of another household (Tahma-Toomas, nääritont, tuhkapoiss, etc.). To be more precise, the loci of the activity have been different. According to earlier records, the direction was neutral, away from the land of one's own community, outside its borders; later it was more biased and directed to the land of another community. Over the course of time, the object at which/whom a concrete ritual was directed became more specific. First it was an area outside of the immediate neighbourhood of one's inner home circle (forest, pasture, thicket), next it was another parish, the territory of another village or the yard of another farm/household, and finally concrete persons to whom the figure was addressed.

It is possible to argue that in the context of sparcely distributed settlements, any departure from the village resulted in ending up in the forest. As forested areas were extensive and numerous, the forest served as a buffer between different communities. With an increase in population density, the development of the administrative system (the establishment of farm and manor boundaries), and the transformation of the peasants' world view, exiting one's own territory was interpreted as entering the territory of another community. At that time, the simple disposal of the figure was replaced by the more specific carrying of it to the land of another village or household. As disagreements between neighbours intensified, the activity may have gradually developed into a deliberate and demonstrative taking of figures to neighbours' households and to certain persons. 
This difference in directionality was also conditioned by the fact that while the metsiku tegemine was a common ceremonial rite, in the 20th century the activities concerning the Tahma Toomas, nääritont, tuhkapoiss, etc. were mostly carried out secretly within the family circle. Here we can view the collective activity as more archaic which, being heretical from the Christian viewpoint and not favourably looked upon by the authorities, retreated from the public sphere into the private domain. 19 Alongside with transformation of the general religious background, the secrecy of the activity has been retained, but later the results of the "carrying contest" were demonstrated as widely as possible.

There have also been shifts in the attitude towards the activity. Initially serious undertakings have been reduced to part of the repertoire of children and young people, and the provocative character of the activity has come to the foreground. It is also of interest to point out that although according to later records, the bearers of the figure were children and not adults, the "serious" meaning of the activity was not lost and existed in parallel with the "new" meanings.

We can argue that the activity was seen as a ritual used to dispel everything unpleasant and bad - all of the aforementioned meanings can be subsumed under this semantic field. According to earlier accounts, the activity was focused on the removal of the figure. A later addition was the notion of more specific localisation of the "bad". The custom was also connected to the concept of limited good: personal good luck or wealth could be obtained only at the expense of others. Once it was believed that the activity made it possible to drive away "bad", then consequently it was believed that retaining the figure meant receiving "bad". At first the figure was perceived as implying something unpleasant and it was undesirable and indecent to be in contact with it. There might also have been a parallel notion of the receipt of the figure as an ill omen followed by something disastrous or unpleasant. At the time when the concept of "bad" inherent in the figure was no longer viable, the figure retained its meaning as a symbol. It was not the figure itself that was "bad" (or if so, then only in an indirect way). The attitude became apparent only through being ridiculed by others. One became an object of disapproval by others when the figure was kept and others noticed this. In this case one was lazy, dirty, etc., and the receipt of the figure became stigmatised in the eyes of bystanders. From there it was not a long way to the notion that the figure was not taken to everyone but only to those who behaved in an unusual or eccentric way. Thus attention was paid to things anomalous, forbidden and indecent, ridiculing whatever was different from accepted everyday patterns of behaviour.

The figure was most often made to be anthropomorphic, i.e. following the proportions and clothing of humans. The choice of materials used has been influenced by what was available at the time of certain folk anniversaries: threshing clothes prior to Christmas, chaff on Christmas, household refuse, dung, ashes, etc. on Shrove Tuesday and Ash Wednesday. Analogously, the meaning given to the activity was linked to other beliefs and customs associated with the respective festivals of the folk calendar.

1991/1997

translated by Mati Limberg. 


\section{Titles of Figures and Maps}

Map no. 1. The making of the metsik (cf. Laakmann, Anderson 1934: 25).

Map no. 2. The driving out of the kada (cf. Lätt 1970: 123).

Photograph no. 1. A straw puppet, Mihkli parish. (Eisen 1931a: 74).

Map no. 3. Making clothed straw figures at Christmas and New Year's Eve (Tahma-Toomas, nääripoiss, etc.).

Photograph no. 2. An ash boy from Karksi parish. Photo: E. Selleke. EFA, Photography Archives, no. 1297.

Photograph no. 3. An ash boy from Karksi parish. Photo: R. Hansen, 1966. EFA, Photography Archives, no. 4986.

Map no. 4. Making clothed straw figures on Ash Wednesday (tuhkapoiss, tuhatüdruk, etc.).

\section{Archive Sources}

Audru 1680 = Laakmann, Anderson 1934: 12;

Hageri 1936: ERA II 91, 701/2 (6) - Pahula Primary School;

Halliste 1930: KKI, WS; 1934: ERA II 78, 526 (6) - R. Viidalepp; 1939: ERA II 214, 560 (5) - A.

Karu; 1940: ERA II 285, 269 (47) - S. Lätt; 1960: RKM II 104, 122/3 (19) - E. Liiv;

Hanila 1678: Th. Hiärne = Laakmann, Anderson 1934: 11-12; 1709: E. Ch. Weidenhain =

Laakmann, Anderson 1934: 13-14; 1890: H II 17, 771 (8) - M. Ostrow; 1896: E 25286/7 (4) - A.

Reimann; 1936: ERA II 195, 456/7 (11) - R. Viidalepp = Lätt 1970: 121; 1968: RKM II 253, 50/1

(7) - L. Briedis = Lätt 1970: 121-122;

Helme 1934a: ERA II 78, 104 (28) - R. Viidebaum; b: ERA II 78, 139 (18) - R. Viidebaum; c: ERA II 78, 143/4 (1) - R. Viidebaum; 1939: ERA II 180, 176/7 (34) - H. Martin; 1936: KKI, WS; 1962a: RKM II 142, 261/2 (11) - E. Tampere; b: RKM II 144, 226/7 (9) - S. Lätt; c: RKM II 145, 490 (5) - O. Jõgever; d: RKM II 145, 502/3 (21) - O. Jõgever;

Juuru: 1929a: ERA II 19, 564/5 (1) - R. Põldmäe = Hiiemäe 1995: 20-21; b: ERA II 19, 565/6 (2) - R. Põldmäe; c: ERA II 19, 566 (3) - R. Põldmäe; d: ERA II 19, 567/8 (4) - R. Põldmäe; g: ERA II 19, 569/70 (8) - R. Põldmäe; 1928-1930: KKI, WS; 1934: KKI, WS; 1987a: RKM II 401, 424/6 (16) - M. Hiiemäe; b: RKM II 401, 449 (6) - M. Hiiemäe; c: RKM II 401, 501 (1) - M. Hiiemäe; d: RKM II 402, 179/80 (19) - A. Korb; e: RKM II 402, 242 (8) - A. Korb; f: RKM II 402, 284 (17) A. Korb; g: RKM II 402, 304 (9) - A. Korb; h: RKM II 402, 301 (29) - A. Korb; i: RKM II 403, 235 (13) - A. Korb;

Jüri 1929: ERA II 20, 358/9 (8) - R. Põldmäe;

Kaarma 1867: Holzmayer III 8, 4 (28); 1872a, b, c: Holzmayer 1872: 10-11 = Laakmann, Anderson 1934: 16-17; 1931: ERA II 34, 147 (48) - O. Loorits;

Karja 1926: E 58390 - G. Ränk = Laakmann, Anderson 1934: 17; 1930: ERA II 23, 717/ 719 - G. Ränk = Laakmann, Anderson 1934: 18; 1932: ERA I 4, 305 (13) - O. Grepp;

Karksi 1933: E 82569a (13) - Vändra Gymnasium of Economics; 1934: ERA II 78, 537 (6) - R. Viidalepp; 1935a: ERA II 88, 54 (76) < Kadrina - M. Saks; 1935b: ERA II 96, 208 (30) - M. Sarv; 1936: KKI, WS; 1960a: RKM II 87, 436/7 (29) - E. Tampere; b: RKM II 87, 475/6 (7) - E.

Tampere; c: RKM II 94, 134 (16) - S. Lätt; d: RKM II 94, 140/1 (8) - S. Lätt; e: RKM II 94, 243/4 (17) - S. Lätt; f: RKM II 94, 362 (11) - O. Jõgever; g: RKM II 94, 474/5 (9) - O. Jõgever; h: RKM II 94, 502 (7) - O. Jõgever; i: RKM II 94, 530 (4) - O. Jõgever; j: RKM II 94, 522 (9) - O. Jõgever; k: RKM II 95, 185 (15) - L. Briedis; l: RKM II 96, 92 (5) - V. Jürken; m: RKM II 96, 115 (30) - V. Jürken; 
Karuse 1693: H. M. Philipp = Laakmann, Anderson 1934: 12; 1889a: H II 2, 196 (304) < Kse - M. Ostrow, O. Kallas = Laakmann, Anderson 1934: 26-27; b: H II 2, 369 (494) - M. Ostrow, O. Kallas = Laakmann, Anderson 1934: 27-28; 1924: E, StK 23, 91 (8) - A. Tiitsmaa = Laakmann, Anderson 1934: 28-29, Lätt 1970: 122; 1929a: ERA II 16, 179 (14) - H. Tampere = Laakmann, Anderson 1934: 29; b: ERA II 16, 184 (6) - H. Tampere = Laakmann, Anderson 1934: 29-30, Lätt 1970: 121; c: ERA II 16, 250 (11) - H. Tampere = Laakmann, Anderson 1934: 30; d: ERA II 16, 257 (1) - H.

Tampere = Laakmann, Anderson 1934: 30-31; 1968: RKM II 254, 32 (14a) - E. Liiv;

Kirbla 1936a: ERA II 195, 327 (7) - R. Viidalepp; b: ERA II 195, 369 (24) - R. Viidalepp;

Koeru 1938: ERA II 183, 597 (25) - L. Priks;

Kose 1936: ERA II 121, 554 (1) - G. Sommer;

Kullamaa 1937a: ERA II 137, 157/8 (9) - V. Eenveer = Hiiemäe 1995: 13; b: ERA II 137, 275/7

(1) - V. Eenveer; 1960: RKM II 101, 125/6 (14c) - J. Nurme; 1990a: EKRK I 90, 196 (6) - T. Roll; b: EKRK I 90, 214/5 (17-18) - T. Roll; c: EKRK I 90, 219/20 (9) - T. Roll; d: EKRK I 90, 221/3 (1) - T. Roll; 1997: CD 0037, 34 - M. Sarv;

Maarja-Magdaleena 1983: RKM II 368, 281 (30) - T. Tammo;

Mihkli 1694: H. Göseken = Laakmann, Anderson 1934: 13; 1894: H III 18, 798 (2) - A. Kappok= Laakmann, Anderson 1934: 31;

Mustjala 1939: ERA II 255, 234 (1) - K. Lepp = Lätt 1970: 121, Tampere 1985: 87;

Märjamaa 1923: E 53585 (33) < Haapsalu - V. Lao; 1929: E 64218 (1) < Haapsalu - V. Lao;

Nõo 1961: RKM I 4, 157 (5) - A. Jõesild;

Otepää 1982: RKM II 361, 206 (4) - M. Raju = Hiiemäe 1995: 135;

Paide 1929: ERA II 14, 23 (33) - R. Viidalepp;

Paistu 1926: E 57217 (8) - I. Kurrik; 1930: E $73103 / 4$ - O. Tanilas; 1937: ERA II 142, 438 (4) - S. Kutti; 1944: RKM II 1, 181/3 (23) - S. Lätt; 1946: RKM II 13, 133 (95) - A. Pikamäe;

Pilistvere 1993a: RKM II 457, 369/70 (8) - M. Hiiemäe; b: RKM II 456, $105 / 6$ (8) - M.-A.

Remmel; c: RKM II 456 - M.-A. Remmel;

Pärnu 1680: J. G. Gerlach = Laakmann, Anderson 1934: 3-6;

Pöide 1947: RKM II 4, 129 (6) - H. Aste = Hiiemäe 1995: 20;

Püha 1974: KKI, KS;

Saarde 1936: ERA II 124, 285 (6) - L. Takk;

Simuna 1960: RKM II 136, 15 (1) - N. Viirmann; RKM II 331, 173 (27) - A. Korb;

Tarvastu 1940: ERA II 270, 253 (15) - J. Veskemäe;

Tõstamaa 1964a: RKM II 175, 438 (21) - M. Proodel; b: RKM II 177, 118 (8) - E. Tampere;

Türi 1966: KKI 39, 652 (5);

Võnnu 1896: E 23570/1 (24) - P. Rootslane;

Vändra 1854: Kreutzwald 1854: 81 = Laakmann, Anderson 1934: 15-16; 1935: ERA II 82, 429 (1)

- Vändra Gymnasium of Economics; 1988a: RKM II 405, 580/1 (16) - S. Karro; b: RKM II 405, 581 (18) - S. Karro;

Äksi 1961a: RKM I 4, 507 (5) - T. Aruoja; b: RKM I 4, 514 (6) - U. Seppius; c: RKM I 4, 551 (2) T. Lindeman.

\section{References}

Ariste, P. 1933. Eesti-rootsi laensõnad eesti keeles. Acta et Commentationes Universitatis

Tartuensis (Dorpatensis), B XXIX (3), Tartu.

Dömötör, D. 1989. Ungarische Volksbräuche. Corvina.

EE $1935=$ Eesti entsüklopeedia V. Tallinn.

Eesti-ma rahva... 1838 = Eesti-ma rahva Kalender, ehk Täht-ramat 1839 aasta peäle. Tallinn.

Eisen, M. J. 1911. Metsik. Eesti Kirjandus, 259-264. 
Eisen, M. J. 1916. Metsik. Eesti Kirjandus, 439-441.

Eisen, M. J. 1931a. Jõuluõled. Eesti Rahva Muuseumi aastaraamat VI. Tartu, 67-80.

Eisen, M. J. 1931b. Meie jõulud. Tartu.

Eisen, M. J. 1995 [1919]. Eesti mütoloogia. Tallinn.

EKS 1994 = Eesti kirjakeele seletussõnaraamat III. Tallinn.

Frazer, J. G. 1983 [1923]. Zolotaja vetv. Moscow.

Haavio, M. 1932. Lohikäärme ja neito. Vertaileva runotutkimus. Suomi 5, 14. Helsinki, 1-96.

Hagu, P. 1975. Setu viljakusjumal Peko. Keel ja Kirjandus 3, 166-173.

Hiiemäe, M. 1987. Rahvakalendri talvepühad. Looming 12, 1678-1687.

Hiiemäe, M. 1995. Eesti rahvakalender VII. Tallinn.

Holzmayer, J. P. 1872. Osiliana. Erinnerungen aus dem heidnischen Göttercultus und alte

Gebräuchte verchiedener Art, gesammelt unter den Insel-Esten. Verhandlungen der Gelehrte

Estnische Gesellschaft 7, 2, Dorpat.

Jaago, T. 1997. Regilaulu varasemast kihist Läänemaal. Läänemaa Muuseumi Toimetised I.

Haapsalu, 113-120.

Juhkam, E. 1992. Eesti rootslastest. Keel ja Kirjandus 7, 394-402.

Kahk, J. 1987. Ristiusk, teadus ja nõiaprotsessid XVII sajandil. Religiooni ja ateismi ajaloost Eestis III. Tallinn, 146-171.

Kalendarnyje... 1977 = Kalendarnyje obychai i obrjady zarubezhnoi Evropy (konets XIX - nachalo

XX veka). Vessennije prazdniki. Moscow.

Kallas, O. 1903. Kraasna maarahvas. Helsinki.

Kreutzwald, F. R. 1854. Der Ehsten abergläubische Gebräuche, Weisen und Gewohnheiten von Johann Wolfgang Boechler. Mit auf die Gegenwart bezüglichen Anmerkungen beleuchtet von Fr. R. Kreutzwald. St. Petersburg.

Laakmann, H., Anderson, W. 1934. Ein neues Dokument über den estnischen Metsik-Kultus aus dem Jahre 1680. Acta et Commentationes Universitatis Tartuensis (Dorpatensis), B XXXII (5), Tartu.

Laugaste, E. 1963. Eesti rahvaluuleteaduse ajalugu I. Valitud tekste ja pilte. Tallinn.

Loorits, O. 1989 [1932]. Eesti rahvausundi maailmavaade. Tallinn.

Loorits, O. 1951. Grundzüge des estnischen Volksglaubens II. Lund.

Lätt, S. 1970. Eesti rahvakalender I. Tallinn.

Madar, M. 1987. Nõiaprotsessid Eestis XVI sajandist XIX sajandini. Religiooni ja ateismi ajaloost Eestis III. Tallinn, 124-145.

Mägiste, J. 1927. L[ääne]m[ere]s[oo]m[e]. keelte kuradinimestikust. Eesti Keel 1-3, 66-84.

Oinas, F. 1992. Viljakusest ja maagiast. Looming 5, 679-686.

Paulson, I. 1997 [1966]. Vana eesti rahvausk. Tartu.

Propp, V. 1963 Russkije agrarnyje prazdniki. Leningrad.

Päss, E. 1931. Lihaheide Eestis. Eesti Rahva Muuseumi Aastaraamat 1930 (VI). Tartu, 5-40.

Põldmäe, R. 1935. Taevakäijad. Kaleviste mailt. Õpetatud Eesti Seltsi Kirjad 3. Tartu, 123-176.

Põldmäe, R. 1965. Hernhuutlik kirjasõna XVIII sajandil ja XIX sajandi algul. Eesti kirjanduse ajalugu I. (Ed. by A. Vinkel) Tallinn, 205-228.

Ränk, G. 1988. Patuoinas ja elupuu. Eesti Teadusliku Seltsi Rootsis Aastaraamat X (1985-1987).

Stockholm, 93-127.

Ränk, G. 1996 [1949]. Vana-Eesti rahvas ja kultuur. Tartu.

Saareste, A. 1958. Eesti keele mõisteline sõnaraamat I. Stockholm.

Saareste, A. 1959. Eesti keele mõisteline sõnaraamat II. Stockholm.

Tampere, H. 1970. Lindude äratamine liivlaste rahvatraditsioonis. Läänemeresoomlaste rahvakultuurist. Tallinn, 193-221. 
Tampere, H. 1975. Eesti rahvapillid ja rahvatantsud. Tallinn.

Tampere, H. ja E. 1985. Vana kannel V. Mustjala regilaulud. Tallinn.

Treumuth, N. 1932. Maakuningas ja mängutoad. Eesti Kirjandus, 17-19.

Troska, G. 1995. Metsik. Eesti rahvakultuuri leksikon. (Ed. by A. Viires) Tallinn, 157.

Vahtre, L. 1991. Eestlase aeg. Uurimus eesti rahvapärase ajaarvamise ajaloost. Tallinn.

Valk, Ü. 1986. Ohverdamine eesti rahvausundis. Vikerkaar 6, 71-74.

Viidalepp, R. 1941. Kildsann ja muid endisaegseid külanoorte kooskäimisi. Eesti Keel ja Kirjandus 1, 47-65.

Viidalepp, R. 1983. Tüdrukute ülalistmine Kihnu saarel. Suomalaisen Ugrilaisen Seuran toimituksia 183. Helsinki, 399-407.

Västrik, E. 1993. Veel metsikust. Eksperimentaalne folkloristika. Tartu.

VMS 1980 = Väike murdesõnastik I. Tallinn.

Waronen, M. 1898. Vainajain palvelus muinaisilla suomalaisilla. Suomalaisen Kirjallisuuden

Seuran Toimituksia 67. Helsinki.

Wiedemann, F. J. 1876. Aus dem inneren und äusseren Leben der Ehsten. St. Petersburg.

Willigerod, J. C. Ph. 1814. Geschichte Ehstlands vom ersten Bekanntwerden desselben bis auf unsere Zeiten. Reval.

\section{Commentaries}

* I am grateful to Mare Kalda, Ülo Valk (Chair of Estonian and Comparative Folklore, Tartu University), and in particular to Laura Stark-Arola (Dept. of Folklore, University of Helsinki) for many helpful suggestions and comments on the original manuscript and translation.

*1 All words that have been judged to have terminological value have been left untranslated and explained in square brackets after their first occurrence. Other Estonian examples have been translated and presented in italics. The apostrophy in transcriptions designates palatalised pronounciation of the preceding letter. The question marks designate translations which have been based on assumptions about the "real" Estonian meaning.

*2 The brackets enclose the supposed completion date of Hiärne's manuscript Ehst-, Lyf- und Lettlaendische Geschichte, although the book was printed as late as 1794. In this text, Hiärne writes about superstitious customs of Estonian peasants and does not provide a more precise determination of location/s. We may, however, surmise that the observations concern the parishes of Hanila and Virtsu as it was there that Hiärne acted as an inspector in 1669 when he began "to gather documents and data about historical heritage" (Laugaste 1963: 304). It should also be noted that Hiärne was deaf, therefore his knowledge about metsik must have been based on some unknown manuscript or personal observation (ibid.).

*3 All texts with original references have been reprinted in Laakmann, Anderson 1934: 3-7, 11-14. For translations into Estonian see Eisen 1911: 259, 1916: 439-441, 1995 [1919], Treumuth 1932: 17-19, Laugaste 1963: 62, 70, 73, Lätt 1970: 93, Valk 1986: 73, Jaago 1997: 114-115. 
*4 Nor are similar 'supertitious customs' mentioned in the minutes of church visitations carried out in South Estonia (Livonia) in the middle of the 17th century, even though the visitations in this region were remarkably more systematic than those in North and West Estonia (see Kahk 1987: 158-162).

*5 More precisely about "Nõelamängulaul" see Jaago 1997.

*6 Information concerning the customs described in the agenda of the calendars published in 18351841 come from either G. H. Schüdlöffel or J. J. A. Hirschhausen (Laugaste 1963: 139).

*7 In association with metsiku tegemine, researchers have frequently mentioned the term tooruse tegemine [making of the toorus $<$ Thor/Taara?]. The author of this paper does not think that this connection can be reasonably substantiated.

*8 This general picture is somewhat contradicted by court records from the Ralli Hans case (1680) which indicate that the figure was, probably to prevent a conflict, but perhaps also to destroy material evidence, carried back to Ralli farm and was publicly burnt in the fireplace of the farmhouse (Pärnu 1680).

*9 In view of the later tradition, the group work sessions of girls which took place in the evenings of Thursdays and Saturdays starting on St. Michael's Day, and where, in addition to working, people danced and partied, can be seen as predecessors of the aforementioned "pagan meetings" (the tradition had been preserved sporadically in peripherial regions of Estonia in the beginning of 20th century, see Viidalepp 1941, 1983).

*10 W. Anderson and E. Laugaste have interpreted the verses in different ways (see Laakmann, Anderson 1934: 5, 36-37, Laugaste 1963: 62). In English translation both interpretations have been used.

*11 The bagpipe was at that time the most popular instrument in Estonia, its use by peasants is mentioned also in the 16.-18. century works of Balthasar Russow, Adam Olearius and Johann Christoph Petri (Tampere 1975: 22).

*12 The protruding genitals of the figure described in the minutes of the ecclesiastical court of Pärnu (1680) might have had the practical function of keeping the puppet upright.

*13 Further parallels can be drawn with a custom in ancient Greece where selected persons were used to cleanse places of disease and other filth: in Athens and other Greek cities it was an annual ritual carried out in May when two people called pharmakoi were led through the city and then driven out with sticks and clubs or torturously executed (Ränk 1988: 109).

*14 According to one record the kada was made of juniper (kadakas) (Karuse 1929c). The interpretation is likely to have been conditioned by the similarity and alliteration of the words.

*15 This specific phrase can also be found in Weidenhain's (Hanila 1709) description of taking away the metsik (see above). It is of interest that the same passage is used in inducements to clean and dust one's living quarters on St. Matthew's Day, and this usage originates from the same or neighbouring parishes as those in which the kadaajamine was known (see Lätt 1970: 177-178). 
*16 Some of the records show that the making of the figure in the parish of Juuru started as late as at the end of the 19th century. It is possible that emigrants from Saaremaa have contributed to the viability of the custom in Juuru. This fact has been pointed out by Mall Hiiemäe, who has mentioned the similarities between the narrative plots and dialectal features of the inhabitants of Saaremaa, and those of Juuru (see also Hiiemäe 1987: 1679-1680).

*17 There are also records which mention the carrying of a baby doll made of Christmas chaff (Tõstamaa 1964a). In Vändra parish the village girls made a big stork, a large rag baby doll was made and put into its peak, and the doll was dressed as about a one-year-old child (Vändra 1988a). According to the account from Jüri parish, Tahma-Toomas was a sooty stone from the threshing barn oven that was taken to the threshing barn of someone else (Jüri 1929).

*18 In rare cases tuhkapoiss has been merely a bag filled with ashes (Halliste 1939, Karksi 1960b). The custom of taking ashes to other households on Ash Wednesday is also known elsewhere in Estonia (see Simuna 1960, 1978, Koeru 1938). A similar custom of attaching small bags of ashes to people's clothes is also familiar as an Ash Wednesday custom in Northern Latvia (Beatrice Reidzane, personal communication on November 12th, 1997).

*19 It is also possible that the change goes in the opposite direction and an individual activity or procedure becomes a ceremony (see for example, the custom of waking of the birds in NorthKuramaa, Tampere 1970: 210). 